\title{
Влияние изменений климата на гидрологический режим реки Амур
}

\author{
МАХИНОВ А.Н., КИМ В.И. \\ Федеральное государственное бюджетное учреждение науки \\ Институт водных и экологических проблем ДВО РАН, Хабаровск \\ amakhinov@mail.ru
}

\begin{abstract}
Аннотация. Рассматривается преобразование гидрологического режима р. Амур, обусловленное глобальным потеплением климата в регионе. На основе проведенного в ИВЭП ДВО РАН анализа трендов температуры воздуха и количества атмосферных осадков на метеостанциях в разных частях бассейна Амура с длительными рядами наблюдений оценены темпы изменений основных метеорологических параметров. Установлено, что на климатические изменения наиболее заметно реагируют амплитуда максимальных годовых уровней воды, активность русловых процессов и смещение сроков ледовых явлений. Они происходят на фоне антропогенного воздействия, роль которого наиболее существенна на локальных участках. Показано, что изменение гидрологического режима в бассейне реки Амур увеличит риск опасных природных процессов в дальневосточном регионе.

Ключевые слова: Амур, изменение климата, наводнения, русловые процессы, ледовые явления.
\end{abstract}

\section{Effect of climate changes on the hydrological regime of the Amur river}

\author{
MAKHINOV A.N., KIM V.I. \\ Institute of the water and ecological problems, FEB of RAS, Khabarovsk \\ amakhinov@mail.ru
}

\begin{abstract}
The transformation of hydrological regime of the Amur River caused by the global warming in the region is considered. Based on the conducted by the IWEP of FEB of RAS analysis of the air temperature and precipitation amount trends at the meteorological stations in different parts of the Amur River basin with longtime series of observations, the rates of changing the basic meteorological parameters were evaluated. It has been established that the amplitude of the maximum annual water levels, activity of the river bed evolution and drift of ice phenomena times react more noticeably to the climatic changes. They come against the background of the anthropogenic impact a role of which is most critical at the local sections. It was shown that a change in the hydrological regime in the Amur River basin will enhance a risk of the dangerous natural processes in the Far-Eastern region.
\end{abstract}

Keywords: Amur-river, climate change, floods, channel processes, ice phenomena.

\section{Введение}

Многолетние изменения климата - одно из основных свойств нашей планеты. Они наряду с антропогенным воздействием приводят к преобразованию природных процессов, создают условия для катастрофических явлений с увеличением их частоты и интенсивности, осложняют условия жизни и хозяйственной деятельности населения. Поэтому повышение экологической безопасности в условиях нарастания негативных природных процессов, обусловленных глобальными климатическими изменениями, уже сейчас 
становится весьма актуальным для различных районов Земли. Данная проблема является достаточно острой для бассейна Амура [1]. Анализ основных природных и антропогенных факторов и причин, обусловливающих интенсивные преобразования природной среды, позволит разработать максимально надежные методы прогнозов ожидаемых последствий опасных явлений, на основе которых возможна подготовка рекомендаций по минимизации их негативного воздействия.

Цель проведенного исследования заключается в оценке влияния климатических изменений в южной части Дальнего Востока на многолетнюю динамику важнейших гидрологических характеристик р. Амур. Основные задачи связаны с выявлением многолетней динамики водного режима реки, в первую очередь, экстремальных паводков, особенностей русловых переформирований в пределах наиболее динамичных участков русла, а также изменении сроков основных ледовых явлений в нижнем течении Амура.

\section{Материал и методы}

По разным модельным расчетам приземная температура воздуха к 2050 г. в масштабах всего земного шара может повыситься на $1-3^{\circ} \mathrm{C}$ [2]. Такое повышение будет равносильно смещению природных зон в равнинной части на 200-300 км к северу, а в горных районах - на 200-300 м вверх по высоте. Полученные в ИВЭП ДВО РАН данные свидетельствуют о существенных климатических изменениях в континентальной части южных районов Дальнего Востока [3, 4]. В Приамурье рост температуры в среднем в 1,5-2 раза опережает глобальный масштаб.

По данным метеостанции Хабаровска в конце 80-х годов прошлого века началось самое значительное потепление, которое продолжается до настоящего времени. Среднегодовая температура воздуха за весь период инструментальных наблюдений с 1891 по 2009 г. возросла на $1,5{ }^{\circ} \mathrm{C}$ (рис. 1), причем только за 20 лет она увеличилась на $0,56{ }^{\circ} \mathrm{C}$ [5]. В последнее десятилетие отмечается самое рекордное увеличение температуры воздуха по сравнению со средними многолетними величинами. Особенно существенным оно было в Среднем и Нижнем Приамурье и происходило в основном за счет потепления зимних и весенних сезонов года. Если тенденция к климатическому потеплению сохранится в первой половине XXI в., то к 2050 г. в южных районах Дальневосточного региона можно ожидать повышение среднегодовой температуры воздуха на 2,5-3,0 ${ }^{\circ} \mathrm{C}$.

Для выявления многолетней динамики водного режима в нижнем течении р. Амур были проанализированы данные ФГБУ «Дальневосточное УГМС» о максимальных уровнях воды за весь период инструментальных наблюдений с 1896 по 2019 г. В результате

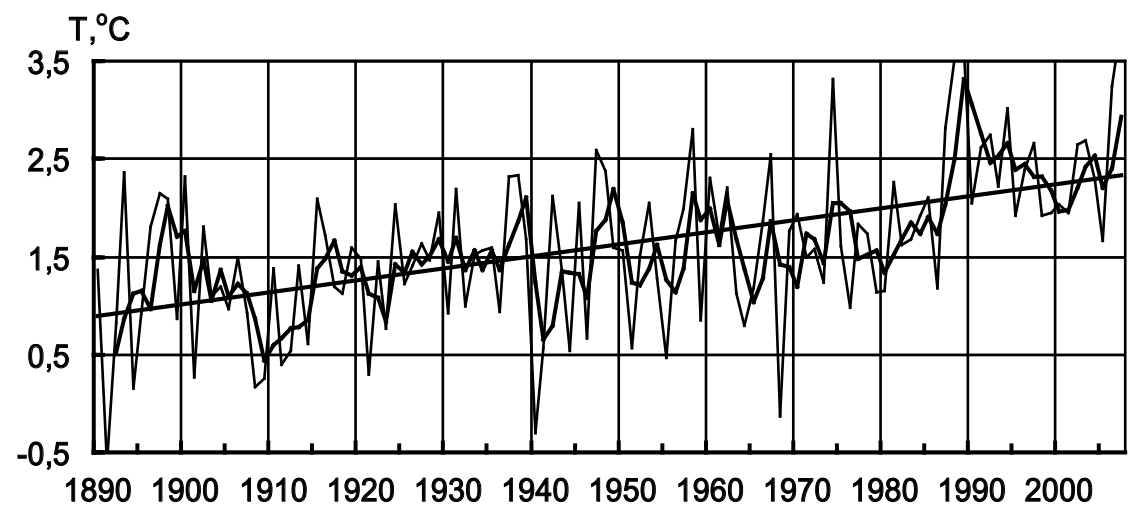

Рис. 1. Изменение средней годовой температуры воздуха по метеостанции Хабаровск. Источник: [4]

Fig. 1. Change in average annual air temperature at the Khabarovsk weather station. Source: [4] 
были выявлены периоды повышенной и пониженной водности и амплитуды экстремальных значений уровней воды в каждом периоде.

При оценке русловых деформаций проводился анализ космических снимков детального разрешения, на которых предварительно были выделены наиболее крупные пойменнорусловые разветвления. Их сравнение с материалами ранее выполненных съемок русла и лоциями рек Амур и Уссури, а также топографическими картами, изданными в разные годы, позволили определить многолетние тенденции в развитии русла в пределах каждого исследуемого участка. Экспедиционные гидрологические работы включали в себя определения морфометрических характеристик основных и второстепенных рукавов р. Амур, картирование динамического состояния берегов. На основе анализа полученных данных выявлялись особенности современной направленности русловых переформирований и их отличий от предшествующих тенденций развития.

Анализ многолетних характеристик ледовых явлений в нижнем течении р. Амур проводился с использованием доступных данных наблюдений на постах ФГБУ «Дальневосточное УГМС», расположенных в различных частях р. Амур и имеющих наиболее продолжительные ряды наблюдений (с 1927-1932 гг.).

\section{Результаты и обсуждение}

В бассейне р. Амур происходят не только изменения климатических показателей, но и направленные преобразования экосистем и их отдельных компонентов. В последние двадцать лет в разных частях амурского бассейна увеличились частота и интенсивность различных природных процессов, нередко достигающих своих экстремальных значений за весь период наблюдений. Среди них следует отметить катастрофические наводнения, рекордно низкие летние уровни воды в реках, изменение сроков ледовых явлений, активизацию крупных оползней и снежных лавин. Многочисленные примеры указывают на ярко выраженную деградацию многолетней мерзлоты на южной границе ее распространения, расширение к северу ареалов южных видов растений и животных. Такая реакция на климатические изменения особенно отчетливо проявляется на водных объектах.

Изменение водного режима. В суровых природных условиях Дальневосточного региона гидрологический режим рек наиболее тесно связан с особенностями климата. Для Амура характерно также четко выраженное естественное многолетнее колебание водности. За все время инструментальных гидрологических наблюдений на Амуре у г. Хабаровск с 1896 по 2019 г. (124 года) периоды повышенной водности отмечались в следующие годы: 1896-1911 (максимальный уровень 642 см), 1927-1938 (616 см), 1951-1964 (634 см), 1981-1998 (620 см). Последний период высокой водности наступил в 2009 г. и продолжается до настоящего времени. Он характеризуется самыми мощными в истории паводками в 2013 и 2019 гг. и наиболее амплитудными изменениями максимальных уровней и расходов воды.

Превышение уровня опасного явления 600 см за это время отмечалось 10 раз, из них четырежды в период с 1951 по 1959 г. Последнее до наводнения 2013 г. превышение уровня 600 см было в 1984 г. Далее, в 1991 г., уровень воды в реке поднимался до 564 см. С тех пор 17 лет на Амуре не было катастрофических наводнений. Наступивший после длительного маловодья период повышенной водности начался в 2009 г., когда максимальный уровень воды по посту Хабаровска достиг 494 см. В нижнем течении Амура была затоплена пойма и подтоплены низко расположенные здания и сооружения. На многих участках реки был отмечен значительный размыв берегов. В последние десятилетия все чаще отмечались локальные наводнения на многих притоках амурского бассейна - на реках Бира, Кур, Хор, Бикин, Большая Уссурка и других они наблюдались в 1996, 2000, 2008, 2013, 2018, 2019 гг.

Катастрофические наводнения на реках Дальнего Востока имеют дождевой генезис [6]. В настоящее время имеются основания считать их значительные масштабы следстви- 
ем изменений путей движения воздушных масс, приносящих в континентальную часть южных районов Дальнего Востока продолжительные интенсивные атмосферные осадки.

Наводнение 2013 г. было обусловлено особенно сильными атмосферными осадками, выпавшими на всей территории бассейна в июле и августе [7, 8]. Несколько циклонов друг за другом сместились в бассейн Амура и задержались здесь, блокированные областью высокого давления на севере и востоке. На значительной площади за 2-3 месяца сумма выпавших осадков превысила годовую, а местами и полуторагодовую норму [9]. Так, за один дождь 22 июля на метеостанции г. Благовещенск выпало 101,3 мм осадков, а за два дня, 8-9 августа, на метеостанции Екатеринославка Амурской области - 139,8 мм. Аналогичные ливни отмечались в бассейнах больших притоков Амура - Бурее, Уссури, Сунгари. Грунты были переувлажнены, и поэтому после каждого дождя почти вся вода быстро сбрасывалась в многочисленные реки, питающие Амур.

Большое значение для формирования столь грандиозного паводка имело уникально совпавшее последовательное наложение пика паводка на Амуре с паводочными волнами всех основных притоков. При движении волны паводка по Амуру ее пик почти день в день совпадал с максимумом паводка на реках Зея, Бурея, Сунгари и Уссури в их устьевых частях [10]. При этом на всех этих больших притоках Амура паводок был не самым значительным за всю историю наблюдений.

Паводок 2019 г. по своим особенностям почти не отличался от катастрофического наводнения на Амуре в 2013 г. Так же, как и тогда, уровень Амура поднимался длительно и непредсказуемо. Поэтому прогнозы постоянно уточнялись, исходя из реально складывающейся ситуации. Различия заключались в том, что начало подъема и конец спада воды происходили несколько быстрее, чем в 2013 г., а в Комсомольске-на-Амуре, по сравнению с Хабаровском, наивысшие отметки были ближе к показателям 2013 г.

Среди антропогенных факторов, усиливающих мощь наводнений, следует отметить наличие искусственных сужений в районах мостовых переходов у городов Хабаровск, Комсомольск-на-Амуре; польдеров и противопаводковых защитных дамб на берегах реки, сокращение лесов и сельскохозяйственное освоение земель. Заметна также аккумулирующая роль крупных водохранилищ ГЭС на территории России и Китая. Очевидно, что определенную роль в формировании больших наводнений последних лет, которую пока сложно оценить количественно, сыграло обезлесивание территории, интенсивно происходящее в конце XX-начале XXI в. в результате масштабных лесоразработок и пожаров в бассейнах, питающих Амур, рек. Изменению условий формирования стока, вероятно, также способствовала распашка земель и осушение болот преимущественно на правобережной части амурского бассейна. Конечно, антропогенные факторы лишь усиливают формирующиеся природными предпосылками наводнения, но их роль с каждым десятилетием становится все более существенной.

К негативным явлениям следует отнести максимально низкие летние уровни воды в нижнем течении р. Амур, наблюдавшиеся в 1992, 2000, 2001, 2002 гг. В 2008 г. был установлен абсолютный минимум максимального летнего уровня воды -65 см.

Многолетняя динамика руслового режима р. Амур. Амур характеризуется высокой динамичностью русловых переформирований. Это проявляется в интенсивном размыве берегов, появлении новых и расширении ранее действовавших рукавов, смещении плесов и перекатов, возникновении обширных кос и островов. Имеющиеся немногочисленные данные о скоростях этих процессов [11], а также сравнения плановых съемок отдельных участков русла Амура за разные годы свидетельствуют о значительной неравномерности интенсивности этих процессов на различных по морфологии участках Амура.

Русло реки в пределах равнинных территорий состоит из множества рукавов различных размеров, образующих исключительно сложную гидрографическую сеть. На многих участках формируются пойменно-русловые разветвления - наиболее сложные и неустойчивые участки реки. Особенно интенсивно преобразование русла происходят в большие паводки, случающиеся один раз в 50-100 лет. В последнее десятилетие отмечается акти- 


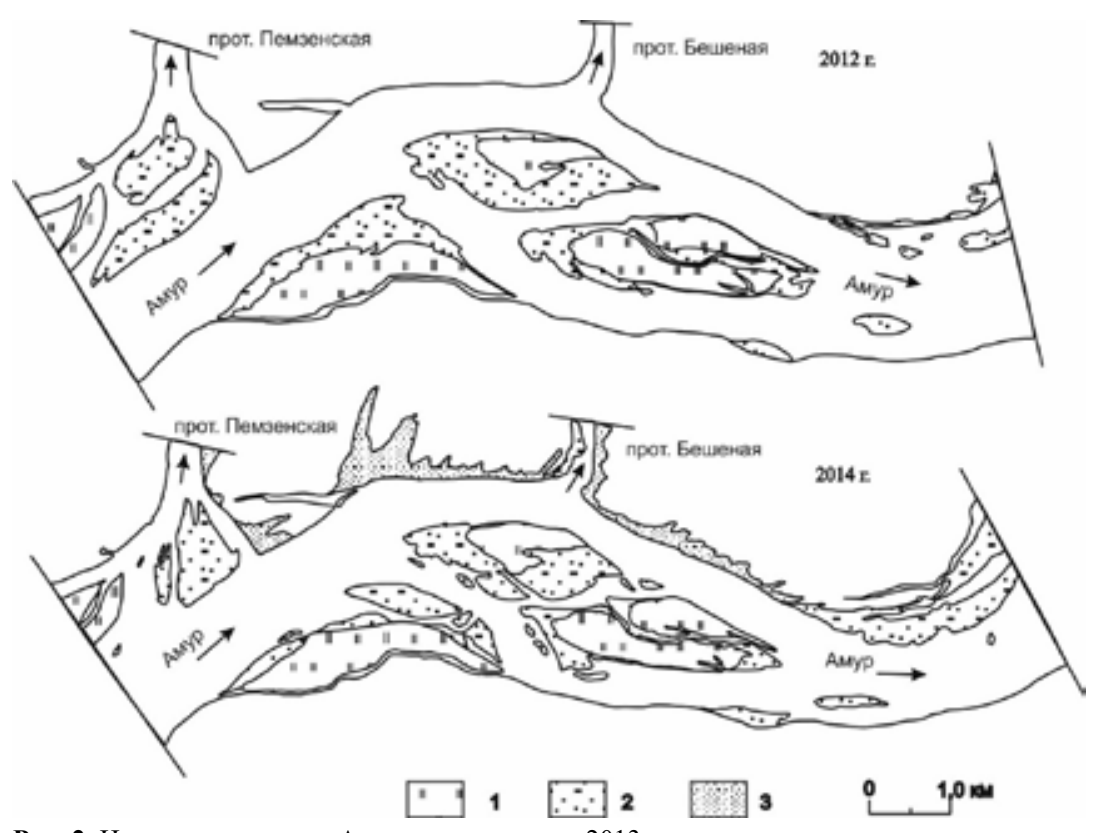

Рис. 2. Изменение русла р. Амур после паводка 2013 г.

1 - пойменные острова; 2 - молодые песчаные косы и осередки; 3 - шлейфы песчаных отложений на пойме

Fig. 2. Change in the Amur river channel after the 2013 flood. 1 - floodplain islands; 2 - young sand-bars and braid bars; 3 - plumes of sandy deposits on the floodplain

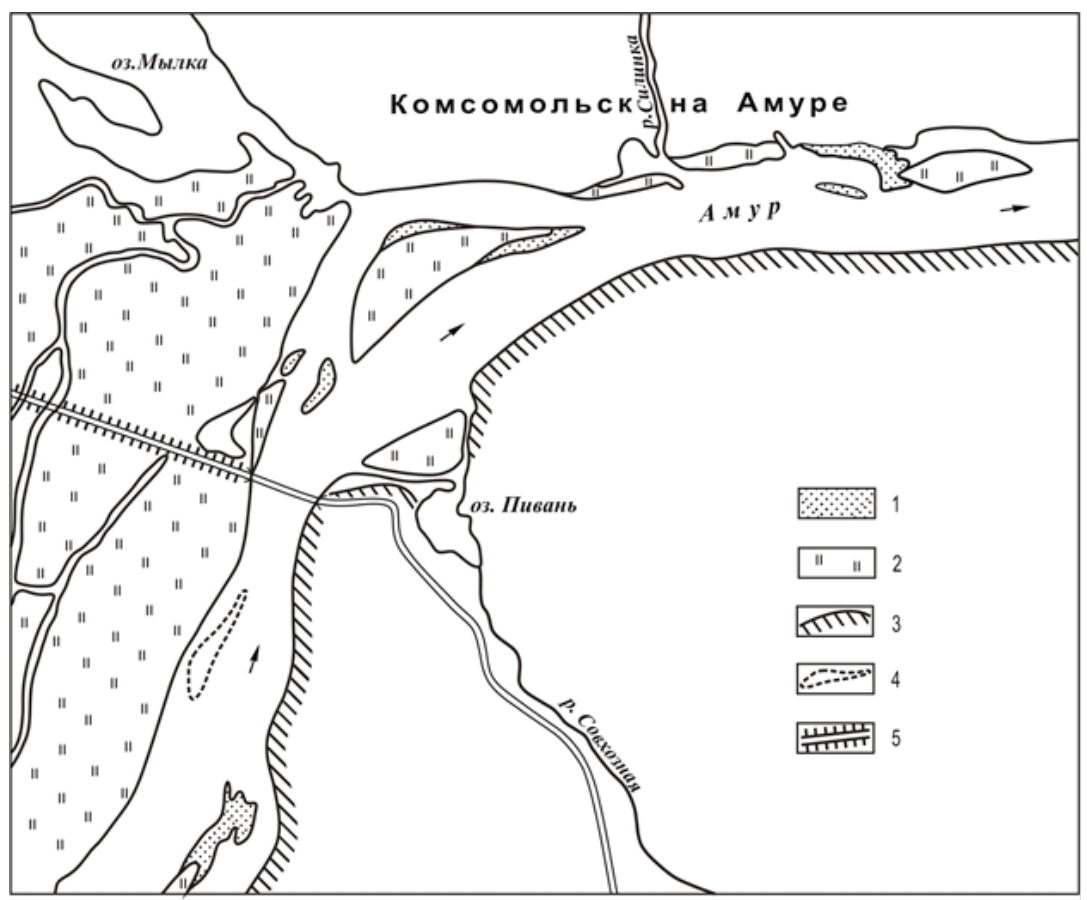

Рис. 3. Интенсивная аккумуляция наносов в левобережном рукаве р. Амур в районе Комсомольска-на-Амуре.

1 - молодые осередки и косы, образовавшиеся во время наводнения 2013 г.; 2 - пойма; 3 - высокий коренной склон долины; 4 - полностью размытый остров; 5 - высокая дамба в пойме.

Fig. 3. Intensive accumulation of sediment in the left arm of the Amur river in the Komsomolskon-Amur region 1 - young sand-bars and braid bars formed during the floods of 2013; 2 - floodplain; 3 - high rocky slope of the valley; 4 - completely washed out island; 5 - high dam in the floodplain. 
визация русловых процессов, что может быть обусловлено прохождением в этот период двух наиболее крупных в истории наводнений на Амуре. Об этом свидетельствуют широкое распространение молодых аккумулятивных форм рельефа в русле, интенсивное перераспределение стока воды по рукавам реки в пойменных расширениях.

Экспедиционные исследования показали, что в русле р. Амур во время наводнения 2013 г. отмечалась особенно высокая активность эрозионно-аккумулятивных процессов. Мощный поток паводковых вод существенно преобразовал русло Амура на всем его протяжении. Анализ космических материалов и данные непосредственных измерений свидетельствуют об изменении морфологических характеристик русел многих основных и второстепенных рукавов р. Амур, увеличении скорости размыва берегов (рис. 2). В одних местах произошел интенсивный размыв дна и увеличились глубины, в других, наоборот, в русле накопилось большое количество песчаных наносов и появились обширные песчаные косы, подводные отмели и острова.

Постоянные деформации русла Амура обусловливают проведение значительных работ по обустройству водных путей. Наиболее остро проблема интенсивных изменений русла проявилась в районе г. Комсомольск-на-Амуре после наводнения 2013 г. У приверха острова, расположенного напротив центральной части города, образовались и увеличились в размерах три крупные песчаные косы, которые будут иметь тенденции к дальнейшему росту (рис. 3). Одна из них сформировалась в истоке ведущего к центральной части города второстепенного рукава, способствуя его дальнейшему отмиранию. Другая обширная песчаная коса образовалась у приверха острова. Они по сути закрывают вход в эту протоку. Третья коса является продолжением острова в его ухвостье и также увеличивается в размеpax, смещаясь одновременно к левому берегу реки в пределах городской черты.

Подобная динамика развития аккумулятивных форм руслового рельефа на этом участке реки приведет к прогрессирующему обмелению протоки и в ближайшей перспективе создаст угрозы для нормального судоходства, что потребует проведения значительных по объему и затратам дноуглубительных работ. Уже сейчас требуется безотлагательное вмешательство для сохранения безопасных условий судоходства на этом участке реки. С целью нейтрализации негативных последствий русловых процессов для судоходства необходимо провести изыскательские работы в русле р. Амур в районе г. Комсомольск-наАмуре и разработать меры по предотвращению развития левобережного рукава.
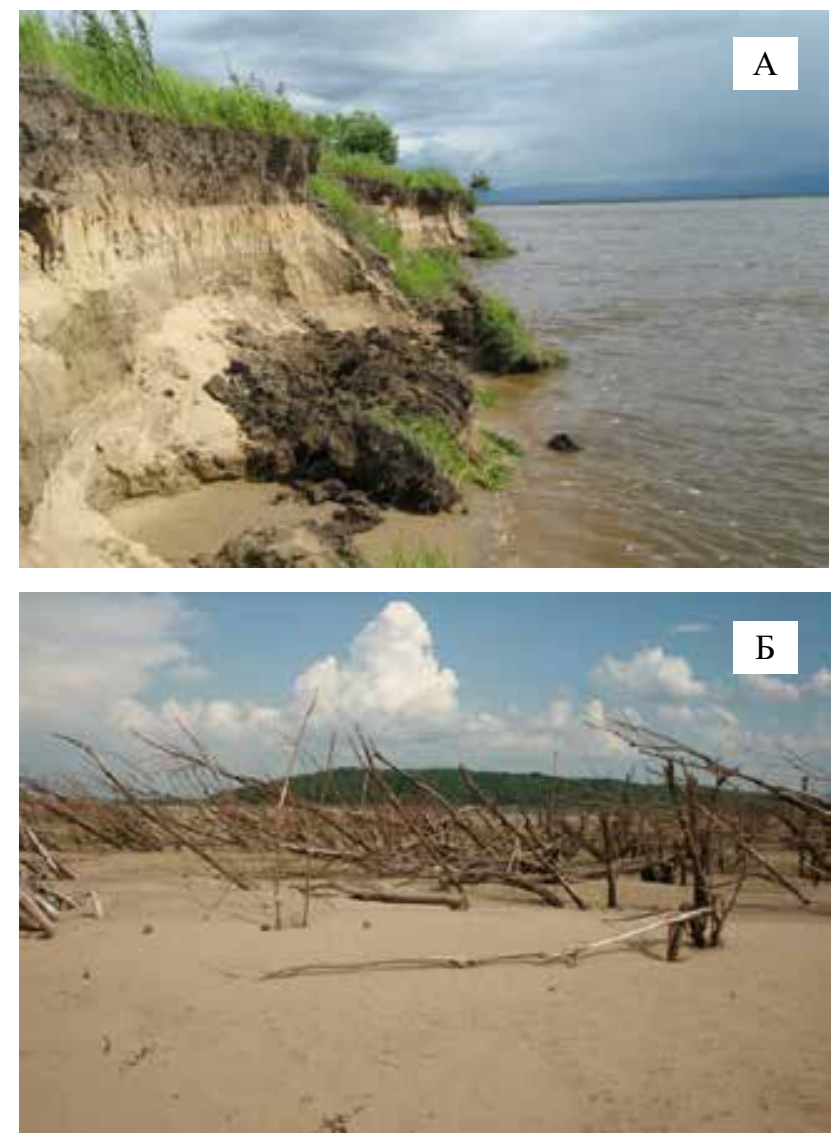

Рис. 4. Эрозия берегов р. Амур (А) и аккумуляция отложений на пойме (Б)

Fig. 4. Erosion of the banks of the Amur river (A) and sediment accumulation in the floodplain (Б) 
Скорость размыва берегов нередко составляет 10-20 м/год, обусловливая активное формирование обширных подвижных кос. Их развитие ведет к дальнейшей фуркации рукавов, уменьшению их транспортирующей способности и накоплению в руслах значительного количества наносов (рис. 4). На отдельных участках реки при перераспределении стока между рукавами происходит размыв берегов даже в зимний период, что характерно для спрямляющих излучину проток.

Динамичные преобразования русла происходят в среднем течении реки, а также в пределах Среднеамурской и Удыль-Кизинской низменностей. Особенно активно эрозионно-аккумулятивные процессы проявляются на участках многофакторного хозяйственного воздействия на русло реки - в окрестностях сел Сергеевка, Константиновка, Поярково в Амурской области, городах Хабаровск, Амурск, Комсомольск-на-Амуре. Аналогичные явления наблюдаются также на участках впадения крупных притоков (реки Бурея, Сунгари и др.).

Ледовый режим. Зимнее потепление вызвало отчетливо выраженные изменения в ледовом режиме Амура [12]. Одно из наиболее легко и надежно определяемых событий - появление первых ледовых образований - заберегов. У Хабаровска они в среднем стали отмечаться 8 ноября, в то время как в предшествующий период появлялись 5 ноября. Следовательно, сроки здесь сдвинулись на три дня (в Комсомольске-на-Амуре и в Николаевске-на-Амуре - на два и шесть дней соответственно). Наибольшие изменения в сроках появления заберегов отмечаются в низовьях реки.

Осенний ледоход на Амуре является важной фазой ледового режима реки, во многом определяющий строение и толщину льда. В среднем течении реки ледостав устанавливается 20 ноября, а в низовьях реки 14 ноября. В последние десятилетия происходило более позднее замерзание реки: в конце ноября-начале декабря. Начало весеннего ледохода на этом же участке реки также сдвинулось на более ранние сроки (рис. 5).

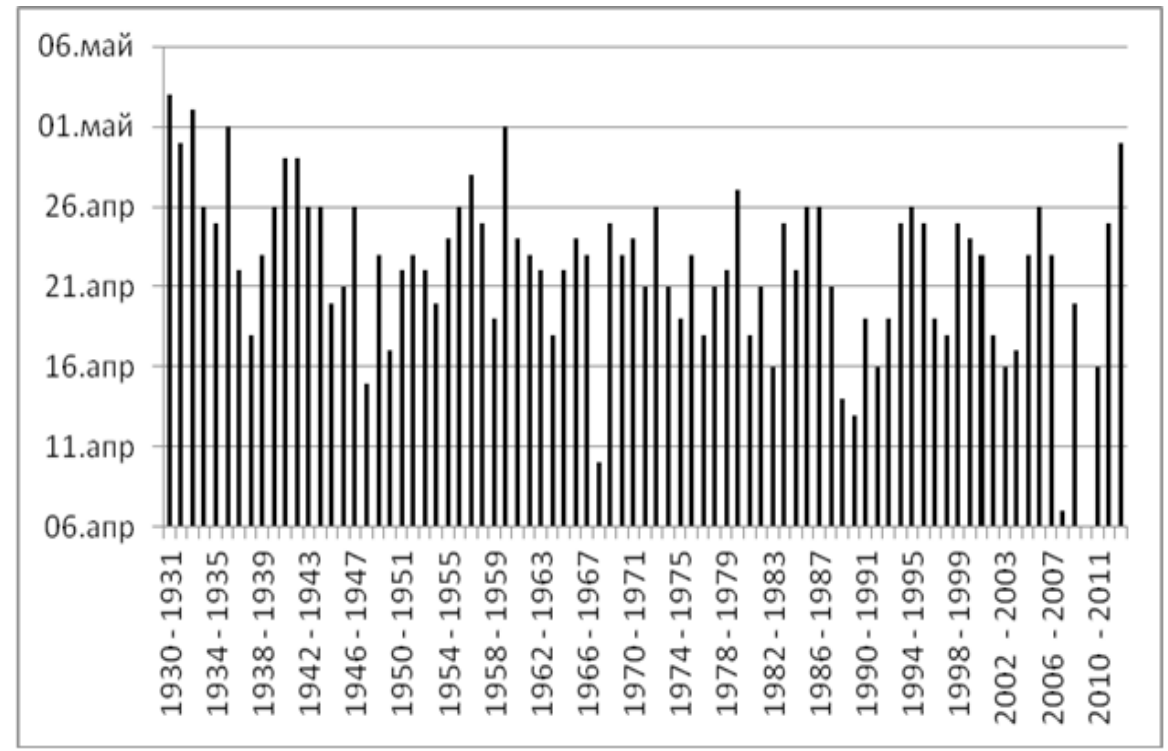

Рис. 5. Даты начала ледохода на р. Амур (г. Хабаровск)

Fig. 5. Dates of ice drift on the Amur river (Khabarovsk)

По данным Дальневосточного УГМС был проведен анализ изменений в сроках наступления различных ледовых явлений за два периода - до 1990 г. включительно и с 1991 по 2013 г. (см. табл.). Сравнение данных о ледовом режиме Амура за эти периоды свидетельствует о том, что начало ледовых явлений сдвинулось на более поздние сроки от 2 до 6 суток. Наибольшие изменения отмечаются в сроках появления заберегов в низовьях 
Изменение ледового режима р. Амур за 1931-2013 гг.

Table. Change in the ice regime of the Amur river for 1931-2013

\begin{tabular}{|c|c|c|c|c|c|}
\hline Годы & $\begin{array}{c}\text { Начало } \\
\text { ледовых } \\
\text { явлений }\end{array}$ & $\begin{array}{c}\text { Начало } \\
\text { ледостава }\end{array}$ & $\begin{array}{c}\text { Начало весеннего } \\
\text { ледохода }\end{array}$ & $\begin{array}{c}\text { Конец весеннего } \\
\text { ледохода }\end{array}$ & $\begin{array}{c}\text { Продолжительность } \\
\text { ледостава }\end{array}$ \\
\hline \multicolumn{6}{|c|}{ Покровка, 2820 км от устья } \\
\hline $1931-1990$ & 19.10 & 09.11 & 01.05 & 07.05 & 173 \\
\hline $1991-2013$ & 20.10 & 12.11 & 28.04 & 06.05 & 169 \\
\hline \multicolumn{6}{|c|}{ Благовещенск, 1941 км от устья } \\
\hline $1931-1990$ & 24.10 & 15.11 & 29.04 & 08.05 & 165 \\
\hline $1991-2013$ & 27.10 & 19.11 & 27.04 & 05.05 & 162 \\
\hline \multicolumn{6}{|c|}{ Хабаровск, 966 км от устья } \\
\hline $1930-1990$ & 05.11 & 23.11 & 23.04 & 29.04 & 151 \\
\hline $1991-2013$ & 08.11 & 24.11 & 21.04 & 27.04 & 148 \\
\hline \multicolumn{6}{|c|}{ Комсомольск-на-Амуре, 614 км от устья } \\
\hline $1932-1990$ & 05.11 & 20.11 & 01.05 & 03.05 & 162 \\
\hline $1991-2013$ & 07.11 & 21.11 & 29.04 & 30.04 & 159 \\
\hline \multicolumn{6}{|c|}{ Николаевск-на-Амуре, 48 км от устья } \\
\hline $1927-1990$ & 01.11 & 13.11 & 15.05 & 16.05 & 184 \\
\hline $1991-2013$ & 07.11 & 15.11 & 12.05 & 14.05 & 179 \\
\hline
\end{tabular}

реки (г. Николаевск-на-Амуре). Они могут быть связаны не только с увеличением температуры воздуха, но и с поступлением сверху по течению из южных участков реки более теплой воды, так как изменения температуры воды более инерционны по сравнению с температурой воздуха.

Ледостав на р. Амур в районе Хабаровска и Комсомольска-на-Амуре после 1990 г. начал устанавливаться на один день позже, чем в предыдущий период, а в Николаевске-наАмуре - на два дня. При этом увеличилась неравномерность начала и окончания ледостава с общим смещением на более поздние сроки начала и на более ранние сроки его окончания. Так, в последние годы ледостав у Хабаровска устанавливался: в 2012 г. - 1 декабря, в 2013 г. - 3 декабря (при средних сроках для этого пункта 24 ноября). Начало ледохода в 2008 г. отмечалось 7 апреля, 2017 г. - 13 апреля (при средних сроках 21 апреля). Продолжительность ледостава на разных участках нижнего течения реки Амур сократилась на 3-4 дня.

Начало весенних подвижек льда и начало весеннего ледохода за последние 23 года сместились по сравнению с предшествующим периодом на трое суток раньше у Хабаровска и Комсомольска-на-Амуре и на двое суток у Николаевска-на-Амуре. Дата окончания весеннего ледохода также сместилась на более ранние сроки на 2-3 дня.

На Амуре более часто стали формироваться полыньи там, где они раньше не возникали. Они образуются в основном русле и в наиболее крупных протоках, достигая 500 м в длину и 200 м в ширину. В их образовании значительную роль играют высокие скорости течения. На отдельных участках реки отмечались случаи зимнего размыва берегов и дна. Наибольшие риски на льду Амура осенью и зимой связаны с опасностью для транспорта и людей провалиться под лед, так как местное население часто использует замерзшее русло реки для движения транспорта. Особенно опасны периодически возникающие полыньи, которые появляются через 3-10 лет приблизительно на одном и том же месте.

Установленное смещение сроков ледовых явлений в нижнем течении реки Амур, несомненно, является реакцией на глобальные климатические изменения, выражающиеся в повышении приземной температуры воздуха и, как следствие, температуры воды. 


\section{Заключение и выводы}

Таким образом, глобальные изменения климата отчетливо проявляются в гидрологическом режиме рек бассейна Амура, обусловливая увеличение частоты и мощности наводнений, размыв берегов рек и неустойчивость ледовых явлений на реках, что требует более тщательного исследования их последствий. Активизация опасных природных процессов, связанная с влиянием климатических изменений и хозяйственной деятельности на фоне динамичных естественных процессов, повышает риск природных катастроф и промышленных аварий, осложняет дальнейшее освоение региона, создает угрозу здоровью и жизни населения.

Большой практический интерес представляет оценка климатических рисков для водных объектов и разработка соответствующих мер адаптации в таких сферах деятельности, как горнодобывающая, лесная и рыбная промышленность, транспорт (особенно речной и прибрежно-морской), энергетика, инфраструктура, сельское и лесное хозяйство, туризм. Эти отрасли, с одной стороны, имеют принципиальное значение для дальнейшего развития юга Дальнего Востока, а с другой - существенно зависят от климатических условий и их направленной изменчивости. Особое внимание необходимо уделить адаптации внутриконтинентальных частей бассейна Амура, так как они наиболее сильно подвержены изменениям природных условий по сравнению с территориями, расположенными непосредственно у морских побережий.

Работа выполнена при частичной поддержке Дальневосточного отделения РАН (проект № 18-5-019).

\section{Литература}

1. Бакланов П.Я., Воронов Б.А. Глобальные и региональные риски устойчивого природопользования в бассейне Амура // Изв. РАН. Серия геогр. 2010. № 2. С. 17-24.

2. Оценочный доклад об изменениях климата и их последствиях на территории Российской Федерации. Т. 1. Изменения климата. М.: Росгидромет, 2008. 227 с.

3. Новороцкий П.В. Климатические изменения в бассейне Амура за последние 115 лет // Метеорология и гидрология, 2007. № 2. С. 43-53.

4. Новороцкий П.В. Современные климатические изменения в бассейне Амура и на побережье Японского моря // Изв. РГО. 2011. Т. 143. Вып. 1. С. 41-48.

5. Новороцкий П.В. Многолетние изменения температуры воздуха и атмосферных осадков в бассейне Нижнего Амура // Метеорология и гидрология. 2004. № 5. С. 55-62.

6. Гарцман Б.И. Дождевые наводнения на реках юга Дальнего Востока: методы расчетов, прогнозов, оценок риска. Владивосток: Дальнаука, 2008. 241 с.

7. Данилов-Данильян В.И., Гельфан А.Н. Экстраординарное наводнение в бассейне реки Амур // Вестн. PAH. 2014. T. 84, № 9. С. 817-825.

8. Махинов А.Н., Ким В.И., Воронов Б.А. Наводнение в бассейне Амура 2013 года: причины и последствия // Вестн. ДВО РАН. 2014. № 2. С. 5-14.

9. Семенов Е.К., Соколихина Н.Н., Татаринович Е.В., Тудрий К.О. Синоптические условия формирования катастрофического наводнения на Амуре в 2013 г. // Метеорология и гидрология. 2014. № 8. С. 25-34.

10. Махинов А.Н. Основные факторы формирования катастрофических наводнений в бассейне реки Амур в 2013 году // Чтения памяти Владимира Яковлевича Леванидова. Владивосток: БПИ ДВО РАН, 2014. Вып. 6. C. $435-442$.

11. Махинов А.Н. Современное рельефообразование в условиях аллювиальной аккумуляции. Владивосток: Дальнаука, 2006. $232 \mathrm{c.}$

12. Махинов А.Н., Ким В.И., Матвеенко Д.В. Строение и многолетняя динамика ледяного покрова в нижнем течении реки Амур // Лёд и Снег. 2018. Т. 58, № 1. С. 117-126.

\section{References}

1. Baklanov, P.Y., Voronov, B.A. Global and regional risks of sustainable nature management in the Amur river basin. News of RAS. Geographical series. 2010. No. 2, p. 17-24. (In Russian) 
2. Assessment Report on Climate Change and its Consequences in Russian Federation. T. 1. M.: Rosgydromet, 2008. $227 \mathrm{p}$.

3. Novorotsky, P.V. Climatic changes in the Amur basin over the past 115 years. Meteorology and Hydrology, 2007, No. 2. P. 43-53. (In Russian)

4. Novorotsky, P.V. Modern climatic changes in the basin of the Amur and on the coast of the sea of Japan. News RGO. Regional Research of Russia, 2011. V. 143, 1: 41-48. (In Russian)

5. Novorotsky, P.V. Long-term changes in air temperature and precipitation in the Lower Amur basin. Meteorology and Hydrology, 2004, No. 5. P. 55-62. (In Russian)

6. Harzman, B.I. Rain floods on the rivers of the south of the Far East: calculation methods, forecasts, risk assessments. Vladivostok: Dalnauka, 2008. 241 p. (In Russian)

7. Danilov-Danilyan, V.I., Gelfan, A.N. Extraordinary flooding in the Amur river basin. Herald of the RAS, 2014, Volume 84, No. 9. P. 817-825. (In Russian)

8. Makhinov, A.N., Kim, V.I., Voronov, B.A. Floods in the Amur basin in 2013: causes and consequences. Vestnik of the Far East Branch of the Russian Academy of Sciences. 2014, № 2. P. 5-14. (In Russian)

9. Semenov, E.K., Sokolikhina, N.N., Tatarinovich, E.V., Tudriy, K.O. Synoptic conditions for the formation of a catastrophic flood on the Amur in 2013. Meteorology and Hydrology, 2014, No. 8. P. 25-34. (In Russian)

10. Makhinov, A.N. The main factors in the formation of catastrophic floods in the Amur river basin in 2013. Readings in memory of Vladimir Yakovlevich Levanidov. Vladivostok: BPI FEB RAS, 2014. Issue. 6, p. 435-442. (In Russian)

11. Makhinov, A.N. Modern relief formation under conditions of alluvial accumulation. Vladivostok: Dalnauka, 2006. 232 p. (In Russian)

12. Makhinov, A.N, Kim, V.I., Matveenko, D.V. The structure and long-term dynamics of the ice cover in the lower reach of the Amur river. Ice and snow, 2018, T. 58, № 1. P. 117-126. (In Russian) 